\title{
OF MICE AND MEN AND TRILLIUM: CASCADING EFFECTS OF FOREST FRAGMENTATION
}

\author{
David A. Tallmon,,${ }^{1,5}$ Erik S. Jules, ${ }^{2}$ Nikki J. Radke, ${ }^{3}$ and L. Scott Mills ${ }^{4}$ \\ ${ }^{1}$ Division of Biological Sciences, University of Montana, Missoula, Montana 59812 USA \\ ${ }^{2}$ Department of Biological Sciences, Humboldt State University, Arcata, California 95521 USA \\ ${ }^{3}$ College of Natural Resources, University of Wisconsin, Stevens Point, Wisconsin 54481 USA \\ ${ }^{4}$ Wildlife Biology Program, School of Forestry, University of Montana, Missoula, Montana 59812 USA
}

\begin{abstract}
Cascading ecological effects of anthropogenic habitat fragmentation have been studied primarily in extreme cases (e.g., the isolation of habitat fragments in a novel habitat matrix such as suburban developments, reservoirs, or agricultural fields), with less attention to more subtle and widespread cases, such as habitat fragmentation due to timber harvest. Few studies have used rigorous demographic data to demonstrate the direct and indirect effects of habitat fragmentation. We trapped deer mice (Peromyscus maniculatus) at five sites over two years in southwest Oregon, USA, and used multi-state capturerecapture models to estimate deer mouse survival and movement in clearcuts, forest-fragment edges, forest-fragment interiors, and contiguous forests. We also estimated deer mouse densities in fragmented and unfragmented forests and combined deer mouse demographic studies with trillium (Trillium ovatum) seed predation trials to link deer mouse changes to reduced trillium recruitment previously observed at the same study sites. Mouse survival was highest in clearcuts, intermediate in forest fragments, and lowest in unfragmented (control) forests. Mouse movement among clearcuts, forest edges, and forest interiors was common over short time intervals. Collectively, demographic rates led to mouse densities that were 3-4 times higher at forest-fragment sites than at unfragmented sites. Trillium seeds were $\sim 3$ times more likely to be depredated in areas of elevated relative mouse abundance than in areas of lower relative abundance. Forest fragmentation has favored mouse populations, resulting in increased seed predation that may decrease recruitment
\end{abstract} rates and increase local extinction risks for trillium.

Key words: demography; edge effects; habitat fragmentation, direct and indirect effects; landscape ecology; Pacific Northwest, USA; Peromyscus maniculatus; plant-animal interactions; population dynamics; trillium recruitment, southwest Oregon, USA.

\section{INTRODUCTION}

Despite evidence for the general importance of direct and indirect effects to community dynamics and widespread fragmentation of native habitats by humans, there are few examples of habitat fragmentation leading to important direct and indirect ecological effects. The few examples that exist are limited to cases in which the modified habitat matrix is extremely different from the remaining intact habitat fragments. In southern California, humans have converted coastal sage-scrub habitat into suburban developments and reduced the presence of coyotes (Canis latrans) in habitat fragments surrounded by the suburban matrix. This appears to have released mesopredators, such as housecats ( $\mathrm{Fel}$ is catus), from predation risk by coyotes and allowed these mesopredators to reduce songbird diversity in habitat fragments (Crooks and Soulé 1999). Dramatic shifts in local species compositions have also followed the isolation of Venezuelan hilltops with a matrix of

Manuscript received 29 March 2002; revised 24 January 2003; accepted 15 February 2003. Corresponding Editor: M. G. Turner.

${ }^{5}$ Present address: Laboratoire d'Ecologie Alpine, UMR CNRS 5553, Universite Joseph Fourier, F-38041 BP 53 Cedex 09, Grenoble, France. E-mail: dtallmon42@yahoo.com water held behind a new dam. The conversion of the former hilltops into small islands in a reservoir has eliminated predators, allowing herbivore numbers to expand and then reduce seedling and sapling densities of a variety of canopy trees (Terborgh et al. 2001). In Argentinian dry forest fragments embedded in an agricultural matrix of crop fields and pastures, fragmentation has reduced pollinator visitation rates to understory plants. This has decreased seed set in several of these plants, possibly affecting their population dynamics (Aizen and Feinsinger 1994).

Most examples of habitat fragmentation are not as extreme as the aforementioned cases. In forests of the U.S. Pacific Northwest, like many regions throughout the world, extensive logging has created patches of intact forest reduced in area and surrounded by a matrix of regenerating clearcuts of young trees (Garman et al. 1999). Fragmented forests are now a dominant feature of the Pacific Northwest. Although remaining old forests show altered physical and biotic characteristics along their edges (Chen et al. 1992, 1995), we do not know of any examples in which direct demographic effects of fragmentation on a single species have translated into indirect impacts on other species in the forest 

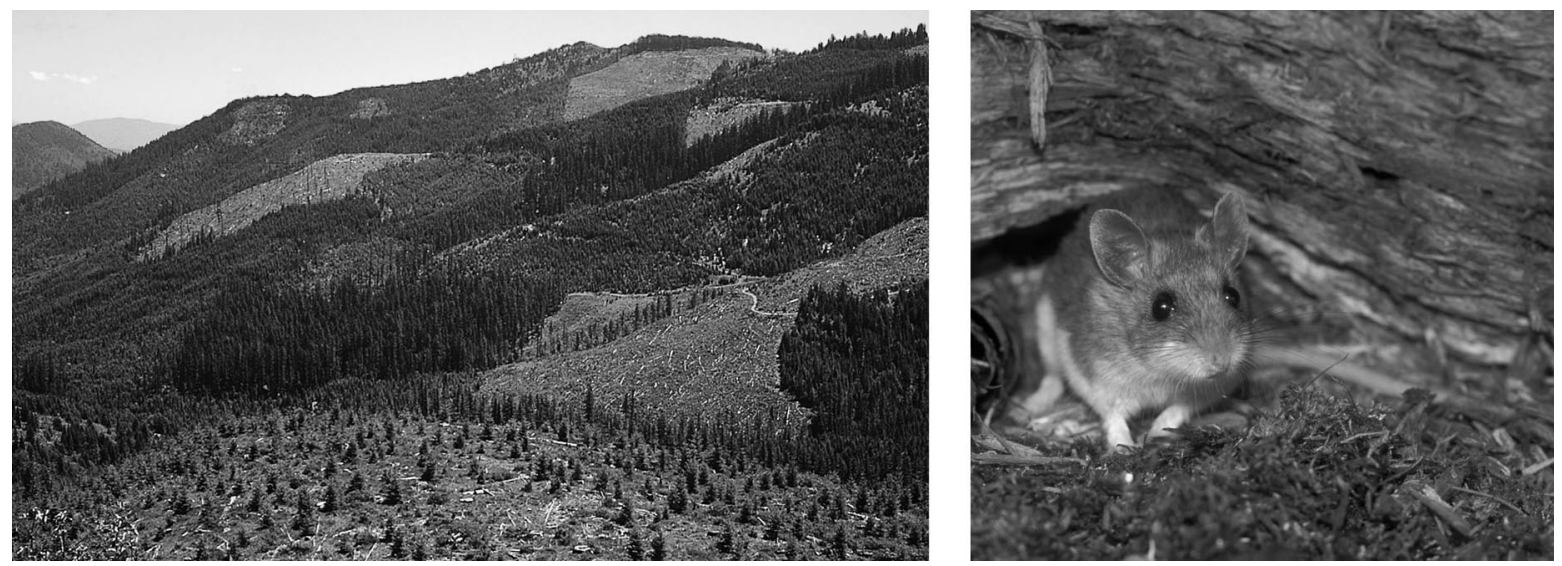

Plate 1. (Left) Fragmented forest landscape by Erik Jules. (Right) Deer mouse (Peromyscus maniculatus) by Milo Burchman.

community. Forests in this region have long been subject to large-scale disturbances, such as moderate and stand-replacing fires (Agee 1993). It is possible that the consequences of habitat fragmentation are not as profound in landscapes where the modified matrix is not completely novel. In these situations, cascading ecological effects may not be an important consequence of fragmentation.

To understand the direct and indirect effects of habitat fragmentation, it is critical to determine demographic responses of single species to fragmentation across the variety of habitats that compose the fragmented landscape, as well as how these responses alter interspecific interactions. Difficulties in rigorously measuring within- and among-population demographic processes have limited most studies to indexing or estimating demographic rates in single habitats or populations (Nichols 1996). Furthermore, information on movement rates among populations remains anecdotal or inferred from indirect measures, especially for vertebrates (Koenig et al. 1996, but see Spendelow et al. 1995, Lindberg et al. 1998, Mills et al. 2003).

We sought to examine the relationship between deer mouse (Peromyscus maniculatus rubidus; see Plate 1) demography and predation of trillium (Trillium ovatum) seeds in fragmented forests where trillium populations are known to have reduced recruitment and increased extinction risk (Jules 1998, Jules and Rathcke 1999). Deer mice have been studied extensively in forests of the Pacific Northwest, but previous studies have not linked deer mouse dynamics across habitats or even reached consensus about the effects of timber harvest on habitat-specific demographic rates. Most studies have found a positive effect of clear-cutting on deer mouse populations (e.g., Tevis 1956, van Horne 1981), but others have suggested that clearcuts have little demographic effect (Petticrew and Sadleir 1974), or may serve as sinks (Sullivan 1979a). At the same sites used in the present study Mills (1996) found an increase in the relative abundance of mice along forest edges and clearcuts. A possible cause for the lack of unity among previous studies is their nearly universal reliance upon counts or indices of abundance and survival to make ecological inferences. Demographic indices confound detection probability (the probability of detecting an individual that is present) with population parameters of interest, such as survival or abundance (Nichols and Pollock 1983). Consequently, demographic indices provide inaccurate measures of population processes when not all individuals present are detected or detection probabilities are not constant across space and time, and should be avoided wherever possible (e.g., Thompson et al. 1998).

If deer mice do show demographic responses to clear-cutting and forest fragmentation (see Plate 1), then this may have important implications for forest plants because mice are important seed predators in many communities throughout North America (e.g., Sork 1984, Willson and Whelan 1990, Ostfelt et al. 1997, Maron and Simms 2001). At some of the same sites used in the present study, Jules (1998) found that trillium populations in clearcuts and along forest-fragment edges are composed primarily of old individuals that have failed to recruit enough individuals to maintain a stable age structure. Consequently, these populations face increased extinction risks. The indirect effects of fragmentation on trillium populations are subtle because these populations contain a large proportion of individuals that successfully produce seeds each year (Jules and Rathcke 1999). Jules (1998) reported that densities of trillium populations in fragment edges are not much lower than the estimate provided for our study area by R. H. Whittaker in 1949, before large-scale logging began (Whittaker 1960). Without knowledge of the age structures of clearcut and fragment populations, which can be determined only by counting annual constrictions on their rhizomes, it would be difficult to discern that these populations have almost no recruitment and elevated extinction risk. However, counts of annual growth constrictions on trillium rhi- 
zomes showed that most of the individuals in these populations were older (up to $72 \mathrm{yr}$ old) than the age of the clearcut, suggesting that the lack of recruitment was related to ecological effects associated with clearcutting (Jules 1998). A series of manipulative studies showed that reduced recruitment in fragments could not be explained by flowering phenology, resource limitation, seed dispersal by insects, seed germination, herbivory, or survival of established plants, but suggested that seed predation by deer mice might be responsible (Jules and Rathcke 1999).

We examined whether the effects of human-caused fragmentation on deer mice have cascaded into negative impacts on trillium recruitment by integrating rigorous studies of mouse demography with trillium-seed predation trials. First, we used a multi-state capturerecapture study to quantify differences in the survival and movement rates of adult deer mice in habitats common to forests of the Pacific Northwest-regenerating clearcuts, forest-fragment edges, forest-fragment interiors, and unfragmented forests. We also investigated whether differences in habitat-specific mouse demographic rates translate into changes in overall population densities. Finally, we linked the demographic changes in trillium observed by Jules (1998) to changes in mouse demography by examining trillium-seed predation rates in areas with high and low abundances of mice. If mouse demography is affected positively by timber harvest, and mice affect trillium recruitment negatively via seed predation, then fragmentation may have subtle, yet important repercussions on plant community dynamics in the Pacific Northwest.

\section{Methods}

\section{Site descriptions and trapping protocols}

During the summers of 1998 and 1999 we trapped mice at five sites in the Siskiyou Mountains of southwest Oregon, USA. All sites are mixed-conifer forests dominated by Douglas-fir (Pseudostuga menzesii) trees and have herbaceous understories. Three sites are forest fragments completely surrounded by clearcuts logged between 1978 and 1987: F1 (3.0 ha), F2 (3.7 ha), and F3 (0.5 ha). F1 and F3 are separated by a common clearcut. F1, F2, and F3 were used by Mills (1996; named $\mathrm{E}, \mathrm{O}$, and $\mathrm{M}$, respectively), and $\mathrm{F} 1$ and $\mathrm{F} 2$ were used by Jules (1998; named I and II, respectively) in previous studies of the ecological effects of habitat fragmentation. We completely covered each fragment with a grid of traps spaced at $15-\mathrm{m}$ intervals, and surrounded each fragment with four transects of six traps each, placed $50 \mathrm{~m}$ into the clearcut from the forest edge (Fig. 1). The number of traps on each fragment was 122 (F1), 154 (F2), and 21 (F3).

We used the same grid and peripheral transect configuration to trap two control sites, C1 and C2, located in unfragmented forest $>150 \mathrm{~m}$ from the southern and northern borders of Oregon Caves National Monument.
Each control site consisted of 102 traps, spaced $15 \mathrm{~m}$ apart in a $17 \times 6$ grid, plus four surrounding transects of six traps each set parallel to each edge of the grid and $50 \mathrm{~m}$ away from the grid in the same unfragmented forest (Fig. 1).

During four trapping sessions each summer we uniquely marked all deer mice captured at each site. Each trapping session lasted four consecutive nights, except for the first trapping session of eight consecutive nights. All four summer sessions were separated by a 16-d interval, except for the first and second sessions of 1998, which were separated by 20 d. Survival and movement estimates are presented as survival and movement probabilities per $20 \mathrm{~d}$. Each evening of each trapping session we baited small Sherman live traps with oat groats, sunflower seeds, $\sim 1 \mathrm{~cm}^{3}$ of fresh apple, and polyester batting, and then placed each trap inside a pint milk container lined with batting. We checked and closed all traps each morning to minimize mortality.

\section{Survival and movement}

We examined variation in deer mouse survival and movement within continuous forest, and among the forest-fragment interior, forest edge, and clearcut using a multi-state modeling approach (Hestbeck et al. 1991, Brownie et al. 1993). In order to use this modeling framework, we assigned each trap at each site to one of six states. At forest-fragment sites, we assigned each grid trap within $30 \mathrm{~m}$ of the forest edge to the "fragment edge state," all grid traps located $>30 \mathrm{~m}$ from the fragment edge to the "fragment interior state," and all traps in the clearcut transects to the "clearcut state" (Fig. 1). Our choice of $30 \mathrm{~m}$ as a break point between the end and interior states seemed justifiable because Mills (1996) found that the relative abundances of mice changed over short distances (15-m intervals) from fragment edge to the interior.

To keep control sites comparable to the fragments, we superimposed an analogous trapping-grid structure by assigning traps $<30 \mathrm{~m}$ from the outer traps of the trapping grid to the "control edge state" and all other grid traps to the "control interior state." Just as the traps in transects surrounding the fragments were assigned to the clearcut, we assigned traps in the transects surrounding the control grids to the "control periphery state" even though they were in the same contiguous mature forest as the main grids. This allowed us to examine whether any observed differences in movement rates among states at fragment sites were an artifact of the trap layout.

We recorded the state-clearcut, fragment edge, fragment interior, control periphery, control edge, control interior-in which each mouse was captured. Mice captured in two states in a single trapping session were assigned to the last state in which they were captured. Thus, we consolidated the capture histories of all individuals to a maximum of a single capture reported 


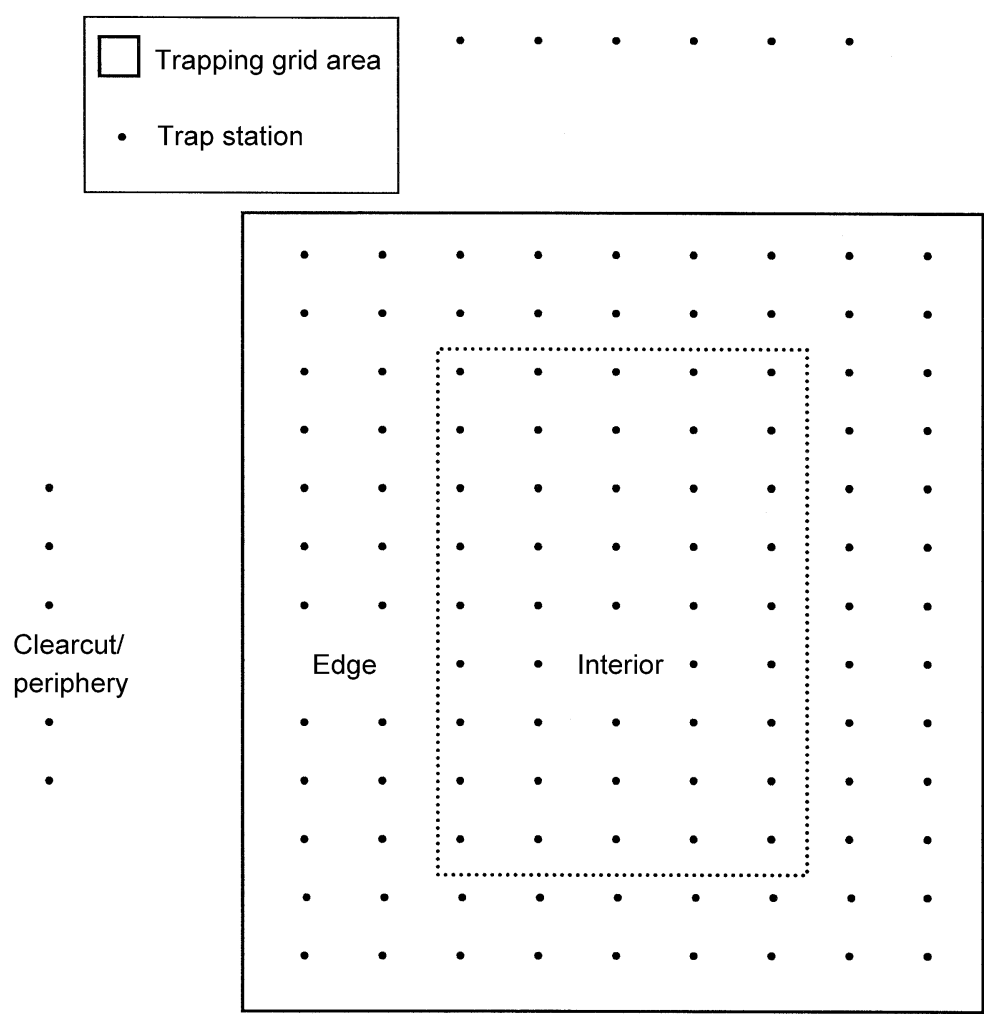

FIG. 1. The general trapping design used to study small mammals on three forest fragments and two unfragmented control sites in southwest Oregon, USA. Fragment sites differed in size and dimensions, but each was completely covered by a trapping grid and surrounded by four transects of six traps spaced $15 \mathrm{~m}$ apart. Transects were placed in the clearcuts surrounding trapping grids at fragmented sites. At control sites, transects in the periphery were located in the same contiguous forest as the trapping grid.

for each session for the analysis of survival and movement.

To examine deer mouse demography, we developed a set of simple candidate models that provided approximations of the underlying dynamics of the study populations based upon our field observations. We avoided complex models that can provide misleading evidence of spurious effects and generally receive little support in most data sets (Anderson et al. 2001). Our models consisted of different combinations of temporal and habitat-specific variation in apparent survival $(\Phi)$, movement $(\Psi)$, and capture $(p)$ probabilities for individuals that did not permanently emigrate from the study sites. Because we were interested in the effects of the different states, or habitats, on survival and movement, we pooled data across sites for each state and across sexes. This allowed us to limit the number of parameters in our candidate models and the number of different models we compared. Consequently, the temporal component of variation in our models included variation in $\Phi, \Psi$, and $p$ among all trapping sessions. The spatial component included variation in these parameters among the three fragment states and among the three control states.

We used program MARK (White and Burnham 1999) to construct multi-state mark-recapture models and to estimate population parameters. Following a modified step-down approach (Lebreton et al. 1992, Langtimm et al. 1998), we constructed a candidate set of 15 models and used Akaike's Information Criteria corrected for sample size $\left(\mathrm{AIC}_{\mathrm{c}}\right)$ to select among competing models in the candidate set. We varied the parameter of least interest, $p$, in each of a series of predetermined candidate models until the optimal parameterization of $p$ was found, and then continued in a similar manner to investigate different parameterizations of $\Psi$, and then $\Phi$. After the 15 preconceived models were run, we ran four more models with new combinations of $p$, $\Psi$, and $\Phi$ from the original models to ensure that we had not mistakenly settled upon a poor approximating model in our original 15 models (Table 1). The model with the lowest $\mathrm{AIC}_{\mathrm{c}}$ value was considered the best 
TABLE 1. The candidate multi-state capture-recapture models used to examine deer mouse apparent survival and movement in fragment $(\mathrm{F})$ and control $(\mathrm{C})$ sites in southwestern Oregon, USA.

\begin{tabular}{|c|c|c|c|c|c|c|c|}
\hline \multicolumn{4}{|c|}{ Model $\dagger$} & \multirow[b]{2}{*}{ Description } & \multirow[b]{2}{*}{$n \neq$} & \multirow[b]{2}{*}{$\Delta \mathrm{AIC}_{\mathrm{c}}$} & \multirow{2}{*}{$\begin{array}{l}\mathrm{AIC}_{\mathrm{c}} \\
\text { weight }\end{array}$} \\
\hline No. & $\Phi$ & $p$ & $\Psi$ & & & & \\
\hline 1 & $\mathrm{~h} \times \mathrm{t}$ & $\mathrm{h} \times \mathrm{t}$ & $\mathrm{h} \times \mathrm{t}$ & $\Phi, p, \Psi$ vary by habitat and time & 168 & 307.81 & 0.00 \\
\hline 2 & $\mathrm{~h} \times \mathrm{t}$ & $\mathrm{h}$ & $h \times t$ & $\begin{array}{l}\Phi, \Psi \text { vary by habitat and time; } p \text { varies } \\
\text { by habitat }\end{array}$ & 132 & 160.40 & 0.00 \\
\hline 3 & $h \times t$ & $\mathrm{~F}(\mathrm{~h}), \mathrm{C}()$. & $h \times t$ & $\begin{array}{l}\Phi, \Psi \text { vary by habitat and time; } p \text { frag- } \\
\text { ment habitat-specific, } p \text { constant } \\
\text { across control habitats }\end{array}$ & 130 & 157.20 & 0.00 \\
\hline 4 & $\mathrm{~h} \times \mathrm{t}$ & . & $h \times t$ & $\begin{array}{l}\Phi, \Psi \text { vary by habitat and time; } p \text { con- } \\
\text { stant across all habitats }\end{array}$ & 127 & 140.54 & 0.00 \\
\hline 5 & $\mathrm{~h} \times \mathrm{t}$ & . & $\mathrm{F}(\mathrm{h} \times \mathrm{t}), \mathrm{C}(\mathrm{t})$ & $\begin{array}{l}\Phi \text { varies by habitat and time; } p \text { constant } \\
\text { across all habitats; fragment } \Psi \text { varies } \\
\text { by habitat and time; control } \Psi \text { varies } \\
\text { by time }\end{array}$ & 92 & 73.83 & 0.00 \\
\hline 6 & $h \times t$ & . & $\mathrm{h}$ & $\begin{array}{l}\Phi \text { varies by habitat and time; } p \text { con- } \\
\text { stant; } \Psi \text { habitat-specific }\end{array}$ & 55 & 57.77 & 0.00 \\
\hline 7 & $\mathrm{~h} \times \mathrm{t}$ & . & $\mathrm{F}(\mathrm{h}), \mathrm{C}()$. & $\begin{array}{l}\Phi \text { varies by habitat and time; } p \text { con- } \\
\text { stant; fragment } \Psi \text { habitat-specific, } \\
\text { control } \Psi \text { constant }\end{array}$ & 50 & 52.68 & 0.00 \\
\hline 8 & $\mathrm{~h} \times \mathrm{t}$ & . & $\mathrm{h}_{\mathrm{o}}$ & $\begin{array}{l}\Phi \text { varies by habitat and time; } p \text { con- } \\
\text { stant; } \Psi \text { habitat-of-origin-specific }\end{array}$ & 49 & 60.04 & 0.00 \\
\hline 9 & $\mathrm{~h} \times \mathrm{t}$ & . & $\mathrm{F}\left(\mathrm{h}_{\mathrm{o}}\right), \mathrm{C}()$. & $\begin{array}{l}\Phi \text { varies by habitat and time; } p \text { con- } \\
\text { stant; fragment } \Psi \text { habitat-of-origin- } \\
\text { specific; control } \Psi \text { constant }\end{array}$ & 47 & 57.02 & 0.00 \\
\hline 10 & $\mathrm{~h} \times \mathrm{t}$ & & . & $\begin{array}{l}\Phi \text { varies by habitat and time; } p, \Psi \text { con- } \\
\text { stant }\end{array}$ & 44 & 96.50 & 0.00 \\
\hline 11 & $\mathrm{~F}(\mathrm{~h} \times \mathrm{t}), \mathrm{C}()$. & & $\mathrm{F}(\mathrm{h}), \mathrm{C}()$. & $\begin{array}{l}\text { fragment } \Phi \text { varies by habitat and time; } \\
\text { control } \Phi \text { constant; } p \text { constant; frag- } \\
\text { ment } \Psi \text { habitat-specific, control } \Psi \\
\text { constant }\end{array}$ & 36 & 28.46 & 0.00 \\
\hline 12 & $\mathrm{~h}$ & & $\mathrm{~F}(\mathrm{~h}), \mathrm{C}()$. & $\begin{array}{l}\Phi \text { habitat-specific; } p \text { constant; fragment } \\
\Psi \text { habitat-specific, control } \Psi \text { constant }\end{array}$ & 14 & 3.49 & 0.08 \\
\hline 13 & $\mathrm{~F}(\mathrm{~h}), \mathrm{C}()$. & & $\mathrm{F}(\mathrm{h}), \mathrm{C}()$. & $\begin{array}{l}\text { fragment } \Phi \text { habitat-specific, control } \Phi \\
\text { constant; } p \text { constant; fragment } \Psi \text { hab- } \\
\text { itat-specific, control } \Psi \text { constant }\end{array}$ & 12 & 0.61 & 0.32 \\
\hline 14 & $\mathrm{~F}(\mathrm{~h}),, \mathrm{C}()$. & . & $\mathrm{F}(\mathrm{h}), \mathrm{C}()$. & $\begin{array}{l}\text { fragment } \Phi \text { habitat-specific (but, edge } \Phi \\
=\text { cut } \Phi), \text { control } \Phi \text { constant; } p \text { con- } \\
\text { stant; fragment } \Psi \text { habitat-specific, } \\
\text { control } \Psi \text { constant }\end{array}$ & 13 & 6.37 & 0.02 \\
\hline 15 & . & & $\mathrm{F}(\mathrm{h}), \mathrm{C}()$. & $\begin{array}{l}\Phi \text { constant; } p \text { constant; fragment } \Psi \text { hab- } \\
\text { itat-specific, control } \Psi \text { constant }\end{array}$ & 9 & 17.36 & 0.00 \\
\hline 16 & $\mathrm{~F}(\mathrm{~h}), \mathrm{C}()$. & & $\mathrm{F}\left(\mathrm{h}_{\mathrm{o}}\right), \mathrm{C}()$. & $\begin{array}{l}\text { fragment } \Phi \text { habitat-specific, control } \Phi \\
\text { constant; } p \text { constant; fragment } \Psi \text { hab- } \\
\text { itat-of-origin-specific; control } \Psi \text { con- } \\
\text { stant }\end{array}$ & 9 & 5.26 & 0.03 \\
\hline 17 & $\mathrm{~F}(\mathrm{~h}), \mathrm{C}()$. & $\mathrm{F}(\mathrm{h}), \mathrm{C}()$. & $\mathrm{F}(\mathrm{h}), \mathrm{C}()$. & $\begin{array}{l}\text { fragment } \Phi \text { habitat-specific, control } \Phi \\
\text { constant; fragment } p \text { habitat-specific, } \\
\text { control } p \text { constant; fragment } \Psi \text { habitat } \\
\text { specific; control } \Psi \text { constant }\end{array}$ & 15 & 0.00 & 0.43 \\
\hline 18 & $\mathrm{~h}$ & $\mathrm{~F}(\mathrm{~h}), \mathrm{C}()$. & $\mathrm{F}(\mathrm{h}), \mathrm{C}()$. & $\begin{array}{l}\Phi \text { habitat-specific; fragment habitat vari- } \\
\text { ation in } p \text {, control constant } p \text {; frag- } \\
\text { ment } \Psi \text { habitat-specific }\end{array}$ & 17 & 2.91 & 0.10 \\
\hline 19 & $\mathrm{~F}(\mathrm{~h}), \mathrm{C}()$. & $\mathrm{F}(\mathrm{h}), \mathrm{C}()$. & $\mathrm{F}\left(\mathrm{h}_{\mathrm{o}}\right), \mathrm{C}()$. & $\begin{array}{l}\text { fragment } \Phi \text { habitat specific, control } \Phi \\
\text { constant; } \Phi ; \text { fragment habitat varia- } \\
\text { tion in } p, \text { control constant } p \text {; fragment } \\
\Psi \text { habitat-of-origin-specific, control } \Psi \\
\text { constant }\end{array}$ & 12 & 6.43 & 0.02 \\
\hline
\end{tabular}

Note: The $\Delta \mathrm{AIC}_{\mathrm{c}}$ value and weight for the best-fitting model is shown in boldface type.

$\dagger$ The model numbers indicate the order in which models were run. Variation included in the models includes time $(\mathrm{t})$ and habitat (h)-specific apparent survival $(\Phi)$, capture $(p)$, and movement $(\Psi)$ probabilities.

$\ddagger$ Number of parameters in each model.

approximating model for our data (Burnham and Anderson 1998). Each model is presented along with its likelihood relative to the other models $\left(\mathrm{AIC}_{\mathrm{c}}\right.$ weight), and difference between its $\mathrm{AIC}_{\mathrm{c}}$ value and the $\mathrm{AIC}_{\mathrm{c}}$ value of the best-fitting model $\left(\Delta \mathrm{AIC}_{\mathrm{c}}\right)$.

\section{Density estimates}

We estimated mouse density at each site during the last trapping session of each summer by dividing the abundance of mice by the effective trapping area. This 
TABLE 2. Closed population models, with different constraints on capture $(p)$ and recapture probabilities $(c)$, used to estimate the abundance of deer mice at fragmented and unfragmented (control) sites in August of 1998 and 1999.

\begin{tabular}{|c|c|c|c|c|c|c|}
\hline \multirow[b]{2}{*}{ Model } & \multirow[b]{2}{*}{ Description } & \multirow[b]{2}{*}{$n \dagger$} & \multicolumn{2}{|c|}{1998} & \multicolumn{2}{|c|}{1999} \\
\hline & & & $\Delta \mathrm{AIC}_{\mathrm{c}}$ & $\begin{array}{c}\mathrm{AIC}_{\mathrm{c}} \\
\text { weight }\end{array}$ & $\Delta \mathrm{AIC}_{\mathrm{c}}$ & $\begin{array}{c}\mathrm{AIC}_{\mathrm{c}} \\
\text { weight }\end{array}$ \\
\hline$p_{(.)} c_{(.)}$ & $p, c$ constant & 6 & 9.96 & 0.01 & 1.01 & 0.36 \\
\hline$p_{(.)}=c_{(.)}$ & $p, c$ constant and equal & 7 & 15.42 & 0.00 & 23.10 & 0.00 \\
\hline$p_{(.)} c_{(\mathrm{T})}$ & $p$ constant; time trend in $c$ & 8 & 29.99 & 0.00 & 89.12 & 0.00 \\
\hline$p_{(\mathrm{t})}=c_{(\mathrm{t})}$ & $p, c$ equal and vary through time & 9 & 12.46 & 0.00 & 20.67 & 0.00 \\
\hline$p_{(\mathrm{s})}=c_{(\mathrm{s})}$ & $p, c$ equal, but site-specific & 9 & 0.00 & 0.90 & 23.70 & 0.00 \\
\hline$p_{(\mathrm{T})} c_{(\mathrm{T})}$ & time trend in $p, c$ & 9 & 11.33 & 0.00 & $\mathbf{0 . 0 0}$ & 0.60 \\
\hline$p_{(\mathrm{s})} c_{(\mathrm{s})}$ & site-specific $p, c$ & 15 & 4.64 & 0.09 & 6.05 & 0.03 \\
\hline$p_{(.)} c_{(\mathrm{T} \times \mathrm{s})}$ & constant $p$; site-specific time trend in $c$ & 16 & 56.60 & 0.00 & 98.02 & 0.00 \\
\hline$p_{(\mathrm{T} \times \mathrm{s})} c_{(.)}$ & site-specific time trend in $p$; constant $c$ & 16 & 39.57 & 0.00 & 70.76 & 0.00 \\
\hline$p_{(\mathrm{T} \times \mathrm{s})} c_{(\mathrm{s})}$ & site-specific time trend in $p$; site-specific $c$ & 20 & 21.20 & 0.00 & 26.07 & 0.00 \\
\hline$p_{(\mathrm{T} \times \mathrm{s})} c_{(\mathrm{T} \times \mathrm{s})}$ & site-specific time trends in $p$ and $c$ & 25 & 21.51 & 0.00 & 23.74 & 0.00 \\
\hline$p_{(\mathrm{t} \times \mathrm{s})} c_{(\mathrm{t} \times \mathrm{s})}$ & time and site-specific $p$ and $c$ & 40 & 38.22 & 0.00 & 30.90 & 0.00 \\
\hline
\end{tabular}

Note: The $\Delta \mathrm{AIC}_{\mathrm{c}}$ value and weight for the best-fitting model each year is shown in boldface type.

$\uparrow$ Number of parameters in each model.

required that we input all daily capture-recapture data collected from each mouse at each site in the last trapping sessions of 1998 and 1999 into MARK (White and Burnham 1999) to generate closed-capture model estimates of abundance (Table 2). As with the multistate models, models were ranked by $\mathrm{AIC}_{\mathrm{c}}$ values. Abundance estimates from the best-approximating model of the candidate set were used in density calculations.

The effective area trapped at each site was estimated following Wilson and Anderson (1985) and Karanth and Nichols (1998). We summed the area covered by the trapping grid and the area between the trapping grid and the traps in the peripheral transects (Fig. 1). Then, we used the mean maximum distance moved by individuals at each site to estimate a boundary width. To determine the effective trapping area, we multiplied the boundary width by the perimeter of the area covered by the trapping grid and added this to the area covered by the grid and peripheral transects.

\section{Seed predation}

We investigated the relationship between mouse demography and trillium-seed predation rates by conducting seed predation trials that took advantage of the linear arrangement of traps in the clearcuts. This study was undertaken in August between the third and fourth trapping sessions of 1999 . We staked a seed platform $\sim 10 \mathrm{~cm}$ off the ground, $5 \mathrm{~m}$ to the north and south sides of the two trap stations with the highest and lowest numbers of mouse captures (out of 12 possible stations) in each of the 11 clearcut transects. Each seed platform consisted of a $10 \times 10 \mathrm{~cm}$ piece of plywood suspended on a $\sim 20$-cm-long nail driven through the center of the plywood and coated with Tanglefoot (Tanglefoot Company, Grand Rapids, Michigan, USA) to prevent ants from ascending. We placed five trillium seeds on each of the two platforms at each station, randomly chose one of the two platforms to serve as a control, and then covered the chosen platform with a strawberry basket to exclude mice and other potential predators.

Our measure of mouse relative abundance was the number of mouse captures at each station during the previous 12 nights of trapping during the 1999 field season. Consequently, the range of mouse captures possible was 0 captures/12 nights to 12 captures/12 nights. We used this measure of the relative abundance for the seed trials rather than absolute abundance because we were concerned only with how frequently any mice were at a station, rather than how many mice occurred at a trap station. By pairing the stations in each clearcut with the highest and lowest number of captures we could control for clearcut-specific differences in mouse relative abundance and still address the question of whether elevated mouse use of an area led to higher trillium-seed predation rates. In addition, by conducting our study in the clearcut we avoided any influences on seed removal rates of the other most common nocturnal species at our study sites, the California redbacked vole, which is abundant in forests and rarely captured in clearcuts (Mills 1995, Tallmon et al. 2002).

We conducted our seed trials during a five-night period prior to the last trapping session of 1999. On the first, third, and fifth nights of this period we placed five seeds on each platform at dusk, and then returned the following dawn to count the number of seeds depredated and to remove any remaining seeds. If any seeds were missing from a control platform, we reduced by the same amount the number of seeds considered depredated from the adjacent treatment platform. We transformed the predation rates (number of seeds depredated per 15 seeds) using an arcsine square-root transformation, and then tested for differences in predation rates between the two trap stations in each clearcut with the lowest and highest numbers of mouse captures using a paired $t$ test. We also regressed seed predation on mouse captures across all stations used in 


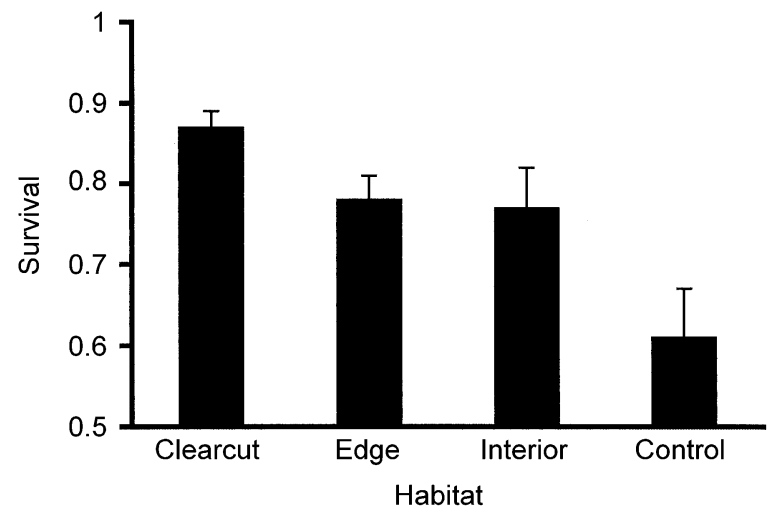

FIG. 2. Habitat-specific deer mouse survival estimates from three forest-fragment sites and two unfragmented control sites in southwestern Oregon, USA. The data are means and $1 \mathrm{SE}$.

the predation experiments to ensure that any relationship between seed predation rates and mouse captures was consistent regardless of analysis method.

\section{RESULTS}

\section{Survival and movement}

A total of 340 individual deer mice captured 710 times were used to examine models of deer mouse survival and movement. Of these, 295 mice were captured at the fragment sites and 45 were captured at the control sites. The best-supported multi-state models were those that contained variation in survival and movement for each of the three fragment states (fragment interior, fragment edge, and clearcut) but not for control states. Two models had the most support, with $\mathrm{AIC}_{\mathrm{c}}$ weights of 0.43 and 0.32 (Table 1). These models differed from each other only in parameterization of the capture probabilities in fragment states, and provided nearly identical point estimates and standard errors for survival and movement rates. Consequently, only results from the best-supported model (highest $\mathrm{AIC}_{\mathrm{c}}$ weight) are presented and discussed. This model contained variation in survival, movement, and capture parameters among the fragment clearcut, edges, and interiors, but only single estimates for the control sites. There was no temporal variation in these parameters in this or any of the other top-ranked models.

Adult survival $(\Phi)$ was highest in clearcuts $(\hat{\Phi}=$ $0.87 \pm 0.02$ [mean $\pm 1 \mathrm{SE}$ ]; Fig. 2). Although survival was clearly lower in fragments than in the clearcuts, there was little evidence for any differences in mouse survival between the fragment edges $(\hat{\Phi}=0.78 \pm 0.03)$ and interiors $(\hat{\Phi}=0.77 \pm 0.05)$. Survival in the unfragmented control sites $(\hat{\Phi}=0.61 \pm 0.06)$ was much lower than in any other habitat we investigated.

Movement rates were generally high at fragment sites and immigration and emigration rates were unique among the interior, edge, and clearcuts of the fragments sites, although greater between adjacent habitats than between distant habitats (Fig. 3). For example, movement $(\Psi)$ from the clearcut to the edge was much higher $(\hat{\Psi}=0.14 \pm 0.03)$ than from the clearcut to the interior $(\hat{\Psi}=0.02 \pm 0.02)$. The interior had the highest emigration rates, with $\hat{\Psi}=0.41 \pm 0.09$ to the forest edge and $\hat{\Psi}=0.17 \pm 0.06$ to the clearcut. In contrast to the fragments, the best-supported model provided only a single movement rate, $\hat{\Psi}=0.24 \pm 0.07$, across the trapping grids and peripheral transects of unfragmented control sites.

Survival and movement estimates were precise due to high capture probabilities that varied from a high of $\hat{p}=1.00 \pm 0.00$ in the clearcut to a low of $\hat{p}=0.89$ \pm 0.03 in the fragment interior. These estimates suggest that we consistently captured most of the trappable individuals present in the deer mouse populations at these study sites each trapping session.

\section{Densities}

In both years of our study, deer mouse densities at fragment and control sites followed the patterns seen in survival rates. Mouse abundances were consistently higher at fragment sites than at control sites (Fig. 4), although the best-approximating abundance models were different in 1998 and 1999 (Table 2). In 1998, 133 mice were captured 532 times in the last trapping session. The best-approximating model had much greater support than any other candidate model $\left(\mathrm{AIC}_{\mathrm{c}}\right.$
FIG. 3. Deer mouse movement estimates among clearcut, edge, and interior habitats at forest-fragment sites in southwestern Oregon, USA. The data are means, with 1 SE in parentheses, and represent the proportion of mice in a habitat type that moved per unit of time (20 d) between trapping periods.

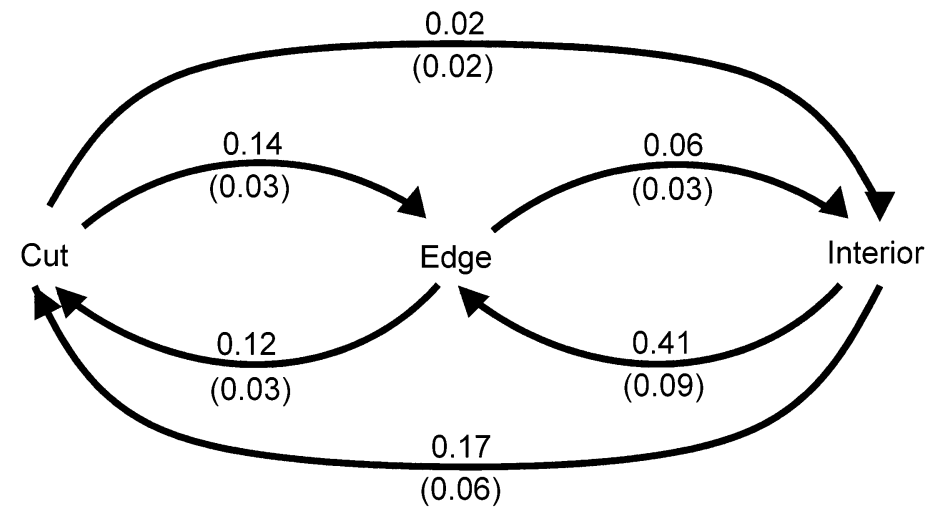




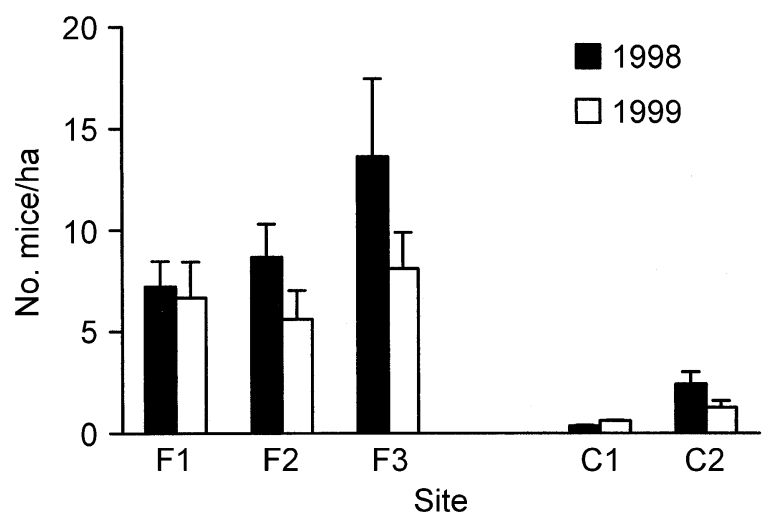

FIG. 4. Deer mouse densities at three forest-fragment and two unfragmented control sites in southwestern Oregon, USA. Data are means and $1 \mathrm{SE}$.

weight $=0.90)$. This model constrained capture and recapture probabilities to be equal to each other, but allowed them to vary by site. Mouse densities at fragment sites ranged from $7.20 \pm 1.23$ to $13.63 \pm 3.83$ mice/ha, and were at least triple the densities of 0.35 \pm 0.04 and $2.42 \pm 0.60 \mathrm{mice} / \mathrm{ha}$ at control sites.

In 1999, 97 mice were captured 385 times in the last trapping session. Two models received far greater support than any other models, with $\mathrm{AIC}_{\mathrm{c}}$ weights of 0.61 and 0.36 (Table 2). These two models differed in their abundance estimates by less than a single individual, so only the best-supported model is discussed. This model included linear time trends in capture and recapture probabilities, but constrained these values to be identical across sites. Mouse densities were uniformly lower across fragment sites in 1999, but were $>4$ times higher than at control sites. Mouse densities ranged from $5.61 \pm 1.40$ to $8.08 \pm 1.80 \mathrm{mice} / \mathrm{ha}$ at fragment sites, and from $0.62 \pm 0.01$ to $1.27 \pm 0.33$ mice/ha at control sites.

\section{Trillium predation}

There was a positive relationship between deer mouse relative abundance and trillium-seed predation rates in our controlled seed predation trials (Fig. 5). The number of mice captured at trap stations in clearcuts ranged from 0 to 8 captures out of 12 possible. Seed predation rates ranged from $0.0(0 / 15)$ to $1.0(15 /$ $15)$ at individual trap stations. Seeds located in areas with higher mouse abundance suffered predation rates that were, on average, nearly three times greater $(0.17$ \pm 0.14 [mean $\pm 1 \mathrm{SE}$ ]) than for seeds located in areas of lower mouse abundance $(0.47 \pm 0.32, n=11 ; t=$ 3.21 , df $=10, P=0.009$ ). In addition, there was a significant linear relationship between mice and seed predation across the range of mouse captures recorded $\left(r^{2}=0.32 ; \mathrm{df}=21, P=0.003\right)$.

\section{DisCUSSION}

Our results provide a link between positive changes in deer mouse demography as a result of habitat frag- mentation and negative demographic changes in trillium. The mouse survival and density estimates reveal evidence of positive effects of fragmentation on deer mouse demographic rates and suggest deer mice are very common in fragmented forests. In addition, we found trillium-seed predation to be higher where mice are more common at sites where Jules (1998) found trillium populations to be recruitment limited. The implications of these results are vast because as much as $85 \%$ of the old-growth Douglas-fir forests in Washington and Oregon (USA) have been harvested (Booth 1991), leaving behind many old forest fragments interspersed with recently clearcut forests in various stages of regeneration (Garman et al. 1999). Because forest fragmentation has occurred on such a large scale in the Pacific Northwest over the past century, the positive effects of fragmentation on deer mouse survival, movement, and densities detected in our study imply that deer mice are probably more common on a regional scale than ever before.

Mouse survival was highest in areas that had been clearcut 10-20 yr prior to our study, moderately lower in forest-fragment edges and interiors, and lowest in unfragmented forests. Interestingly, all 12 mice captured in 1998 that survived to be recaptured in 1999 were from the fragment edges and clearcuts; none from the fragment interior habitat or the control sites were recaptured in the 1999 field season. We found no differences in survival between fragment edges and interiors, but this could be due to the fact that the entire fragment sites may be largely edge influenced. Chen et al. (1995) found edge effects from clearcuts influenced microclimatic variables from $30 \mathrm{~m}$ up to $>240$ $\mathrm{m}$ into Douglas-fir forests of the Cascade Range. Survival estimates did not differ across the control trapping grids in unfragmented forest sites, which reflects the homogeneity in structure and physical properties within these intact forests relative to that seen across the clearcuts and forests of the fragment sites.

Deer mouse movement rates also varied across the fragment edges, interiors, and surrounding clearcuts.

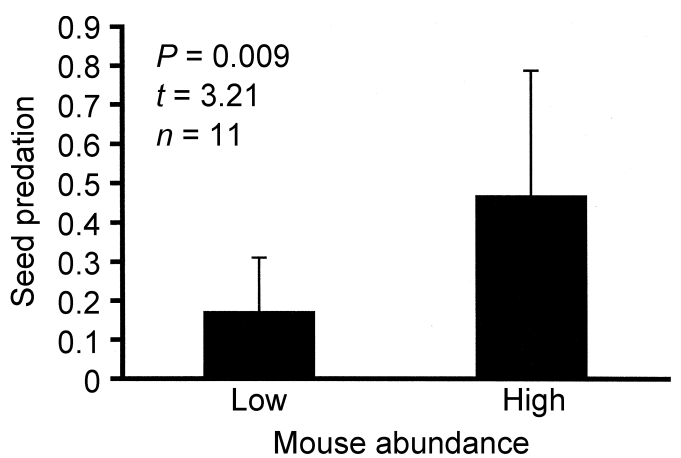

FIG. 5. The proportion of trillium seeds depredated by mice at trap stations with the highest and lowest relative mouse abundances in each clearcut transect. Data are means and $1 \mathrm{sE}$. 
For example, more than half of the mice captured in fragment interiors were recaptured in the surrounding edge or clearcut the next trapping session. In contrast, closer to $15 \%$ of the mice captured in the edges and clearcuts were recaptured in a different habitat the next trapping session. However, it should be noted that fewer individuals were captured in the fragment interiors than in the edges or clearcuts, so the absolute numbers of movement events are not as disparate as the immigration and emigration rates might suggest. Nevertheless, these immigration and emigration rates suggest that deer mice move freely among the edge, interiors, and clearcuts of fragmented forests. Movement rates among forest habitats have not previously been addressed using a rigorous mark-recapture framework, although deer mouse dispersal events of several hundred meters have been documented (Gashwiler 1959, van Horne 1981).

The demographic rates documented here provide novel insights into deer mouse population structure. By using a rigorous mark-recapture framework, we avoided the pitfalls of demography indices that confound detection probabilities with demographic responses to treatments (Thompson et al. 1998), and found clear positive effects of forest fragmentation on deer mice. It appears that deer mouse demes in these forests consist of individuals that move frequently across the various habitats that compose the fragmented landscape (Fig. 3). As a result of high rates of movement across forest-fragment edges, interiors, and clearcuts, mouse demography in any single habitat may be strongly influenced by fitness in other nearby habitats.

The differences in mouse survival rates between fragment sites and unfragmented control sites are mirrored by differences in mouse densities. Densities of mice were $\geq 3$ times higher at fragment sites than control sites late in the breeding season (August) of both years of our study. In some respects, these results are not surprising because previous modeling efforts have demonstrated the importance of adult survival to population growth rate of this species. Analyses of matrix projection models of deer mouse demographic vital rates have shown that the geometric population growth rate, or dominant eigenvalue of the projection matrix (Caswell 2001), is more sensitive to proportional infinitesimal changes in adult survival than any other vital rate (Citta 1996). Consequently, we would anticipate that even small differences in adult survival would translate into large impacts on habitat-specific population growth rates and overall densities. In this study, large differences in adult-mouse survival rates were detected between the fragmented forest habitats and the controls, and these differences appear to have contributed to strong population-level numeric responses to fragmentation. All of our results show positive demographic responses of deer mice to forest fragmentation and suggest that clearcuts may serve as a demographic source in these forests (Pulliam 1988).
The positive effects of forest fragmentation on deer mice may have important implications for trillium. Deer mouse densities were estimated in August, which coincides with the height of trillium seed set at these sites (D. Tallmon, personal observation). Mouse densities are high in fragmented forests at the same time trillium are producing seeds. In our seed predation trials, higher relative abundances of mice led to higher trillium-seed predation rates. Several lines of evidence suggest that mice, and not some other species or factor, removed the seeds in our predation trials. First, these trials were conducted at night when most other potential seed predators (birds and chipmunks) or dispersers (insects) are inactive. In addition, mice comprised over $95 \%$ of all captures in traps placed in clearcuts, which suggests that other rodents did not greatly influence our results. Finally, we found mouse feces on six uncovered platforms from which seeds had been removed, but never on platforms that were not depredated. Feces of other species were not observed on any platforms.

The positive effects of human-caused fragmentation on deer mice and the negative effects of deer mice on trillium seeds may link human-caused vegetation removal to demographic changes in trillium. The present study shows that deer mouse survival is highest in clearcuts, that mice are more common in fragmented forests than unfragmented ones, and that trillium-seed predation rates are indeed higher in areas where mice are more common. Although the removed seeds may have been cached rather than directly eaten by mice, the trillium populations at these sites show little recruitment following clear-cutting. This suggests that whether seeds are initially cached or eaten, they are probably removed from these populations. Interestingly, mice ate seeds but left behind eliasomes on two platforms in our seed predation trials, but never took eliasomes and left seeds behind. This suggests that mice consume trillium seeds and not just nutrient-rich trillium-seed eliasomes.

A number of plants in the Siskiyou Mountains of northwestern California and southwestern Oregon may be negatively affected by clear-cutting (Jules et al. 1999). Of these, species that produce large seeds or fruits may well have lower recruitment rates as an indirect result of positive direct effects of forest harvest on deer mice. For example, manipulative studies have shown that deer mice are the most important Douglasfir seed consumers in clearcuts (Gashwiler 1970, Sullivan 1979b). In the eastern United States it has already been shown that deer mice influence tree recruitment, and thus future forest structure and composition, along the edges of old-fields (Ostfeld et al. 1996, 1997). It is likely that seed predation by mice interacts with other impacts of logging, such as changes in microhabitat qualities and disperser populations, to alter trillium and other plant population dynamics in fragmented forests (Meier et al. 1995). Whether mice will respond negatively to forest regeneration in clearcuts over the com- 
ing decades is an important question. This may release plants at these sites, such as trillium, from seed predation pressure and allow them to rebound. How interspecific interactions change temporally in managed landscapes is of critical importance, but remains a largely unexplored research area.

Our results show positive effects of fragmentation on deer mice, and suggest that indirect effects of clearcutting in these forests may include a negative feedback loop that negatively influences trillium recruitment. Habitat fragmentation has led to dramatic changes in deer mouse population dynamics that are detectable in the demographic rates that vary across the habitat types common in this fragmented landscape and in the high densities of mice in fragmented areas. Trillium-seed predation rate is greater where mice are more common, providing evidence of indirect effects of anthropogenic fragmentation of Pacific Northwest forests. This suggests that cascading ecological effects may be an important consequence of habitat fragmentation, even in cases where the modified habitat matrix does not differ greatly from the remaining habitat patches.

\section{ACKNOWLEDGMENTS}

We thank Brent Danielson, Doug Emlen, Mark Lindberg, Mike Schwartz, and Monica Turner for helpful comments on earlier drafts of this manuscript. M. Lindberg provided sage advice on multi-state capture-recapture analyses. This project was made possible by efforts from many excellent field assistants too numerous to name, but special thanks are due to Gong Ji'en, Kingsford Jones, and Mandy Stone. D. Tallmon was supported by National Science Foundation (NSF) Graduate Training Grant (DGE 9553611). USDA Competitive Grant 97-35101-4355 and NSF MONTS 291835 and DEB 9870654 grants to L.S. Mills also supported this research.

\section{Literature Cited}

Agee, J. K. 1993. Fire ecology of Pacific Northwest forests. Island Press, Washington, D.C., USA.

Aizen, M. A., and P. Feinsigner. 1994. Forest fragmentation, pollination, and plant reproduction in a Chaco dry forest, Argentina. Ecology 75:330-351.

Anderson, D. R., K. P. Burnham, W. R. Gould, and S. Cherry. 2001. Concerns about finding effects that are actually spurious. Wildlife Society Bulletin 29:311-316.

Booth, D. E. 1991. Estimating prelogging old-growth in the Pacific Northwest. Journal of Forestry 89(10):25-29.

Brownie, C., J. E. Hines, J. D. Nichols, K. H. Pollock, and J. B. Hestbeck. 1993. Capture-recapture studies for multiple strata including non-Markovian transition probabilities. Biometrics 49:1173-1187.

Burnham, K. P., and D. R. Anderson. 1998. Model selection and inference: a practical information-theoretic approach. Springer-Verlag, New York, New York, USA.

Caswell, H. 2001. Matrix population models. Sinauer Associates, Sunderland, Massachusetts, USA.

Chen, J., J. F. Franklin, and T. A. Spies. 1992. Vegetation responses to edge environments in old-growth Douglas-fir forests. Ecological Applications 2:387-396.

Chen, J., J. F. Franklin, and T. A. Spies. 1995. Growingseason microclimatic gradients from clearcut edges into old-growth Douglas-fir forests. Ecological Applications 5: 74-86.

Citta, J. J. 1996. How to change the growth of wildlife populations: applications and experimental tests of sensitivity analysis. Thesis. University of Montana, Missoula, Montana, USA.

Crooks, K. R., and M. E. Soulé. 1999. Mesopredator release and avifaunal extinctions in a fragmented system. Nature 400:563-566.

Garman, S. L., F. J. Swanson, and T. A. Spies. 1999. Past, present and future landscape patterns in the Douglas-fir region of the Pacific Northwest. Pages 61-86 in J. A. Rochelle, L. A. Lehmann, and J. Wisniewski, editors. Forest fragmentation: wildlife and management implications. Brill, Boston, Massachusetts, USA.

Gashwiler, J. S. 1959. Small mammal study in west-central Oregon. Journal of Mammalogy 40:128-139.

Gashwiler, J. S. 1970. Further study of conifer seed survival in a western Oregon clearcut. Ecology 51:849-854.

Hestbeck, J., J. D. Nichols, and R. A. Malecki. 1991. Estimates of movement and site fidelity using mark-resight data of wintering Canada Geese. Ecology 72:523-533.

Jules, E. S. 1998. Habitat fragmentation and demographic change for a common plant: trillium in old-growth forest. Ecology 79:1645-1656.

Jules, E. S., E. J. Frost, L. S. Mills, and D. A. Tallmon. 1999. Ecological consequences of forest fragmentation: case studies from the Siskiyou region. Natural Areas Journal 19: 368-378.

Jules, E. S., and B. J. Rathcke. 1999. Mechanisms of reduction in trillium recruitment along edges of old-growth forest fragments. Conservation Biology 13:784-793.

Karanth, U. K., and J. D. Nichols. 1998. Estimation of tiger densities in India using photographic captures and recaptures. Ecology 79:2852-2862.

Koenig, W. D., D. van Vuren, and P. N. Hooge. 1996. Detectability, philopatry, and the distribution of dispersal distances in vertebrates. Trends in Ecology and Evolution 11: 514-517.

Langtimm, C. A., T. J. O'Shea, R. Pradel, and C. A. Beck. 1998. Estimates of annual survival probabilities for adult Florida manatees (Trichechus manatus latirostris). Ecology 79:981-997.

Lebreton, J. D., K. P. Burnham, J. Clobert, and D. R. Anderson. 1992. Modeling survival and testing biological hypotheses using marked animals: a unified approach with case studies. Ecological Monographs 62:67-118.

Lindberg, M. S., J. S. Sedinger, D. V. Derksen, and R. F. Rockwell. 1998. Natal and breeding philopatry in a black brant, Branta bernicla nigricans, metapopulation. Ecology 79:1893-1904.

Maron, J. L., and E. L. Simms. 2001. Rodent limited establishment of bush lupine: field experiments on the cumulative effect of granivory. Journal of Ecology 89:578-588.

Meier, A. J., S. Power Bratton, and D. Cameron Duffy. 1995. Possible mechanisms for loss of vernal-herb diversity in logged eastern decicuous forests. Ecological Applications 5:935-946.

Mills, L. S. 1995. Edge effects and isolation: red-backed voles on forest remnants. Conservation Biology 9:395403.

Mills, L. S. 1996. Fragmentation of a natural area: dynamics of isolation for small mammals on forest remnants. Pages 199-219 in R. G. Wright, editor. National Parks and Protected Areas. Blackwell Science, Cambridge, Massachusetts, USA.

Mills, L. S., M. K. Schwartz, D. A. Tallmon, and K. P. Lair. 2003. Measuring and interpreting changes in connectivity for mammals in coniferous forests. In C. J. Zabel and R. G. Anthony, editors. Management and conservation in the coniferous forests of Western North America. Cambridge University Press, Cambridge, UK, in press.

Nichols, J. D. 1996. Sources of variation in migratory movements of animal populations: statistical inference and a 
selective review of empirical results for birds. Pages 147197 in O. E. Rhodes, R. K. Chesser, and M. H. Smith, editors. Population dynamics in ecological space and time. University of Chicago Press, Chicago, Illinois, USA.

Nichols, J. D., and K. H. Pollock. 1983. Estimation methodology in contemporary small mammal capture-recapture studies. Journal of Mammalogy 64:253-260.

Ostfeld, R. S., C. G. Jones, and J. O. Wolff. 1996. Of mice and mast: ecological connections in eastern deciduous forests. BioScience 46:323-330.

Ostfeld, R. S., R. H. Manson, and C. D. Canham. 1997. Effects of rodents on survival of tree seeds and seedlings invading old fields. Ecology 78:1531-1542.

Petticrew, B. G., and R. M. F. S. Sadleir. 1974. The ecology of the deer mouse Peromyscus maniculatus in a coastal coniferous forest. I. Population dynamics. Canadian Journal of Zoology 52:107-118.

Pulliam, H. R. 1988. Sources, sinks, and population regulation. American Naturalist 132:652-661.

Sork, V. L. 1984. Examination of seed dispersal and survival in red oak, Quercus rubra (Fagaceae), using metal-tagged acorns. Ecology 65:1020-122.

Spendelow, J. A., J. D. Nichols, I. C. T. Nisbet, H. Hays, G. D. Cormons, J. Burger, C. Safina, J. E. Hines, and M. Gochfeld. 1995. Estimating annual survival and movement rates of adults within a metapopulation of Roseate Terns. Ecology 76:2415-2428.

Sullivan, T. P. $1979 a$. Demography of populations of deer mice in coastal forest and clear-cut (logged) habitats. Canadian Journal of Zoology 57:1636-1648.

Sullivan, T. P. $1979 b$. Repopulation of clear-cut habitat and conifer seed predation by deer mice. Journal of Wildlife Management 43:861-871.
Tallmon, D. A., H. Draheim, L. S. Mills, and F. W. Allendorf. 2002. Insights into recently fragmented vole populations from combined genetic and demographic data. Molecular Ecology 11:699-709.

Terborgh, J., L. Lopez, P. Nunez, M. Rao, G. Shahabuddin, G. Orihuela, M. Riveros, R. Ascanio, G. H. Adler, T. D. Lambert, and L. Balbas. 2001. Ecological meltdown in predator-free fragments. Science 294:1923-1926.

Tevis, L. 1956. Responses of small mammal populations to logging of Douglas-fir. Journal of Mammalogy 37:189196.

Thompson, W. L., G. C. White, and C. Gowan. 1998. Monitoring vertebrate populations. Academic Press, San Diego, California, USA.

van Horne, B. 1981. Demography of Peromyscus maniculatus population in seral stages of coastal coniferous forest in southeast Alaska. Canadian Journal of Zoology 59:10451061.

White, G. C., and K. P. Burnham. 1999. Program MARK: survival estimation from populations of marked individuals. Bird Study Supplement 46:120-138.

Whittaker, R. H. 1960. Vegetation of the Siskiyou Mountains, Oregon and California. Ecological Monographs 30:279338.

Willson, M. F., and C. J. Whelan. 1990. Variation in postdispersal survival of vertebrate-dispersed sees: effects of density, habitat, location, season, and species. Oikos 57: 191-198.

Wilson, K. R., and D. R. Anderson. 1985. Evaluation of two density estimators of small mammal population size. Journal of Mammalogy 66:13-21. 